\title{
Effect of dietary supplementation of biofloc meal on growth and survival of GIFT tilapia
}

\author{
E. PRABU, C. B. T. RAJAGOPALSAMY, B. AHILAN, JEGAN MICHAEL ANDRO JEEVAGAN \\ AND M. RENUHADEVI \\ Fisheries College and Research Institute, Tamil Nadu Fisheries University, Thoothukudi - 628 008, Tamil Nadu, India \\ e-mail: prabufcri@gmail.com
}

\section{ABSTRACT}

A 60 days indoor growth trial was conducted to study the effect of dietary supplementation of biofloc meal on growth and survival of juvenile GIFT tilapia. Four isonitrogenous and isoenergetic experimental diets (32\% crude protein) were prepared using biofloc meal at different inclusion levels viz., 0 (T0), 20 (T1), 30 (T2) and 40\% (T3). A commercial diet (T4) was used for comparison. The feeding trial was conducted in 15 nos. of 401 plastic troughs in triplicate, utilising GIFT tilapias weighing an average of $2 \mathrm{~g}$. During the experimental period, water quality parameters were measured and recorded daily. The mean value of water temperature, $\mathrm{pH}$, dissolved oxygen, salinity, ammonia- $\mathrm{N}$, nitrite- $\mathrm{N}$, nitrate- $\mathrm{N}$, hardness and alkalinity recorded in the experimental systems were $28.5^{\circ} \mathrm{C}, 8.1,5.5 \mathrm{ppm}, 4.5 \mathrm{ppt}, 0.03 \mathrm{ppm}, 0.07 \mathrm{ppm}, 11 \mathrm{ppm}, 630 \mathrm{ppm}$ and $162.5 \mathrm{ppm}$ respectively. Among the biofloc meal enriched diets, diet $\mathrm{T} 1$ with $20 \%$ biofloc yielded the best results in terms of average body weight gain, feed conversion ratio (FCR), specific growth rate (SGR), protein efficiency ratio (PER) and feed efficiency ratio (FER). The mean body weight gain recorded in T1 was $25.28 \pm 0.81 \mathrm{~g}$. The results demonstrated that biofloc meal is a potential ingredient that can be incorporated in GIFT tilapia diet at $20 \%$ level for better growth performance.

Keywords: Biofloc meal, Fish meal, GIFT tilapia, Protein feed, Soybean meal

\section{Introduction}

Aquaculture is the fastest growing sector of global fish production (FAO, 2010). Approximately 40\% of fish from aquaculture originates from tilapia production (Scorvo-Filho et al., 2010). Today, tilapia has become the shining star of aquaculture, which is also popular as 'aquatic chicken' and the rate of its consumption has increased across the globe (Fitzsimmons, 2005). Annual global production of cultured tilapia has increased consistently in recent years (Ahsan et al., 2013). The GIFT strain was developed by International Centre for Living Aquatic Resources Management (ICLARM; presently World Fish Centre, WFC) through several generations of selection from the base population involving 8 different strains of Nile tilapia Oreochromis niloticus (Eknath and Hulata, 2009). Feed costs in aquaculture can be reduced by the adoption of biofloc technology, since the expenses with commercial diets account for more than $50 \%$ of the production cost. Biofloc contains up to $30 \%$ crude protein and about 2\% lipids (Azim and Little, 2008; Ballester et al., 2010; Xu and Pan, 2012; Luo et al., 2014). Biofloc contains adequate levels of protein, lipid, carbohydrate and ash and is suitable for use as an ingredient in aquaculture feed (Crab et al., 2010). In this context, the present study was planned to evaluate inclusion of biofloc meal at different levels in the diet of GIFT tilapia.

\section{Materials and methods}

Experimental fish

GIFT tilapia seeds were procured from the State Fisheries Department, Krishnagiri, Tamil Nadu, India. They were acclimatised in FRP tanks, by nursing for 15 days feeding on a commercial diet. They were graded according to weight prior to the experiment. One hundred and fifty numbers of GIFT tilapia having average weight of $2 \mathrm{~g}$ were selected for the trial.

\section{Experimental design}

The trial was conducted in the indoor biofloc laboratory of Fisheries College and Research Institute, Thoothukudi, Tamil Nadu, India. The 60 days indoor growth experiment carried out in plastic troughs of 401 , consisted of five dietary treatments with three replicates each. Water was filled in the troughs upto $3 / 4^{\text {th }}$ of the volume. All the troughs were provided with proper aeration facility.

\section{Biofloc collection and analysis}

Biofloc was collected using a plankton net of $100 \mu \mathrm{m}$ mesh size from Hi-Tide sea farm, Mahendrapally, Nagapattinam District, Tamil Nadu, India. Totally $23 \mathrm{~kg}$ 
of wet biofloc was collected and dried under sunlight for $8 \mathrm{~h}$. The total quantity of dried biofloc meal obtained was $2.1 \mathrm{~kg}$. It was powdered into fine particles and stored in an air tight container under refrigeration. The proximate composition of the biofloc meal was analysed following standard protocols (AOAC, 1995).

\section{Experimental diets}

Four isonitrogenous and isoenergetic experimental diets were formulated viz., T0, T1, T2 and T3. A control diet (T0), without biofloc was compared against the three prepared diets formulated with different levels of biofloc at 20 (T1), 30 (T2) and 40\% (T3) by manipulating fish meal and soybean meal level. A commercial diet (T4) was used as an external control. The ingredient composition of the experimental diets is presented in Table 1. method (APHA, 2005) was adopted to estimate dissolved oxygen. Total alkalinity was determined as per the method described in APHA (2005). Total ammonia-N, nitrite-N, nitrate- $\mathrm{N}$, water hardness and turbidity were assessed twice a week, following standard methods (APHA, 2005).

Sampling

Fish sampling was done every fortnight, collecting all the stocked fish from each tank to measure total length and body weight.

\section{Growth performance}

Growth performance was assessed in terms of feed conversion ratio (FCR), feed efficiency ratio (FER), protein efficiency ratio (PER), specific growth rate (SGR),

Table 1. Ingredient composition of the formulated feed

\begin{tabular}{lllll}
\hline \multirow{2}{*}{ Ingredient } & \multicolumn{3}{c}{ Inclusion level (\%) } \\
\cline { 2 - 5 } & Control (T0) & $20 \%$ Biofloc (T1) & $30 \%$ Biofloc (T2) \\
\hline Biofloc meal & 0 & 20 & 30 & $40 \%$ Biofloc (T3) \\
Fish meal & 22 & 26 & 27 & 27 \\
Cassava starch & 18 & 15 & 13 & 10 \\
Soybean meal & 26 & 15 & 10 & 5 \\
Rice bran & 22 & 12 & 5 & 6 \\
Fish oil & 5 & 5 & 3 & \\
Fish hydrolysate & 3 & 3 & 2 & \\
Monocalcium phosphate & 2 & 2 & 0.5 & 3 \\
Vitamin premix & 0.5 & 0.5 & 0.5 & 1 \\
Mineral premix & 0.5 & 0.5 & 1 & 0.5 \\
Common salt & 1 & 1 & 0.5 \\
\hline
\end{tabular}

The proximate composition of all the experimental diets (T0 - T4) was estimated following standard protocols (AOAC, 1995).

\section{Stocking and feeding}

Fish of $2 \mathrm{~g}$ mean weight were stocked at 10 nos. per plastic trough. After stocking, the experimental troughs were covered with plastic net on the top in order to prevent fish jumping out of the troughs.

Feeding was done thrice a day (at 9: 00; 12: 00 and 16: $00 \mathrm{hrs)} \mathrm{ad} \mathrm{libitum.} \mathrm{Each} \mathrm{of} \mathrm{the} \mathrm{experimental} \mathrm{diets} \mathrm{was}$ fed by hand slowly to avoid wastage. Feed was given until apparent satiation.

\section{Water quality parameters}

During the experimental period, water quality parameters such as temperature, dissolved oxygen, $\mathrm{pH}$, and total alkalinity were measured daily. Water temperature was measured using a thermometer with an accuracy of $0.1^{\circ} \mathrm{C}$. $\mathrm{pH}$ of water was measured using the laboratory model Elico pH meter. Modified Winkler's titration mean weight gain and survival estimated using the following formulae:

$$
\begin{aligned}
& \text { Feed conversion ratio }(\mathrm{FCR})=\text { Total feed fed }(\mathrm{g}) / \text { Total fish weight } \\
& =\frac{\ln \text { Final weight }-\ln \text { Initial weight }}{\text { Experimental duration in days }}
\end{aligned}
$$

\section{Statistical analysis}

Data were analysed by one-way ANOVA using the statistical software SPSS 16.0 for windows (SPSS Inc., 
Chicago, IL, USA) and also by Duncan multiple range test (Duncan, 1995).

\section{Results}

\section{Water quality parameters}

The range of water quality parameters such as temperature, dissolved oxygen, $\mathrm{pH}$ and total alkalinity recorded in the experimental systems are presented in Table 2.

Table 2. Range of water quality parameters recorded in the experimental troughs

\begin{tabular}{ll}
\hline Parameter & Range \\
\hline Temperature & $28-29^{\circ} \mathrm{C}$ \\
Dissolved oxygen & $5-6 \mathrm{ppm}$ \\
$\mathrm{pH}$ & $8-8.2$ \\
Salinity & $4-5 \mathrm{ppt}$ \\
Ammonia & $0.01-0.05 \mathrm{ppm}$ \\
Nitrite & $0.05-0.1 \mathrm{ppm}$ \\
Nitrate & $10-12 \mathrm{ppm}$ \\
Hardness & $610-650 \mathrm{ppm}$ \\
Alkalinity & $155-170 \mathrm{ppm}$ \\
\hline
\end{tabular}

\section{Proximate composition of experimental diets}

Proximate composition of the experimental diets is presented in Table. 3. Dried biofloc contained 17.92\% crude protein, $0.15 \%$ crude fibre, $0.41 \%$ ether extract, $51.28 \%$ total ash, $10.06 \%$ moisture and $1864 \mathrm{kcal} \mathrm{kg}^{-1}$ gross energy. The percentage crude protein content of the prepared experimental diets ranged from $32.54 \pm 0.07$ to $32.74 \pm 0.05$.

\section{Growth performance}

The calculated growth parameters for the experimental diets are shown in Table. 4. Highest mean body weight of GIFT tilapia was recorded in the control $(27.16 \pm 0.50 \mathrm{~g})$, followed by $\mathrm{T} 1(25.28 \pm 0.81 \mathrm{~g})$, T2 $(22.10 \pm 0.24 \mathrm{~g}), \mathrm{T} 3(20.46 \pm 1.34 \mathrm{~g})$ and T4 (19.88 $\pm 0.99 \mathrm{~g})$. However, the mean body weight in T1 (20\% biofloc meal) did not differ significantly from the control. FCR, SGR, PER and FER showed significant difference among the treatments $(p<0.05)$. The feed conversion ratio $(F C R)$ of diets T0, T1, T2, T3 and T4 was $1.11 \pm 0.01,1.19 \pm 0.01$, $1.25 \pm 0.01, \quad 1.31 \pm 0.01, \quad 1.37 \pm 0.01$ respectively. The respective feed efficiency ratio (FER) was $0.90 \pm 0.01$, $0.84 \pm 0.01,0.80 \pm 0.01,0.76 \pm 0.01$ and $0.73 \pm 0.01$. Protein efficiency ratio (PER) of diets $\mathrm{T} 0, \mathrm{~T} 1, \mathrm{~T} 2, \mathrm{~T} 3$ and $\mathrm{T} 4$ was $7.41 \pm 0.10,6.89 \pm 0.08,5.93 \pm 0.15,5.45 \pm 0.22$ and $4.90 \pm 0.74$ respectively. Specific growth rate (SGR\%) recorded was $4.32 \pm 0.04,4.21 \pm 0.05,3.99 \pm 0.03,3.89 \pm 0.08$ and 3.84 \pm 0.07 respectively for fish fed diets T0, T1, T2, T3 and T4 (Table 4; Fig.1).

\section{Discussion}

Nutritional composition of biofloc varies according to the environmental condition, carbon source applied, total suspended solid level, salinity, stocking density, light intensity as well as with changes in phytoplankton and bacterial communities. Protein content of biofloc in the present study was $17.92 \%$ which tallies with the earlier findings of Soares (2004), Hende et al. (2014) and Neto et al. (2015), whereas lesser values of biofloc crude protein was reported by Magondu (2012) and Megahed (2014). The lipid content of biofloc in this study was $0.41 \%$,

Table 3. Proximate composition of the experimental diets

\begin{tabular}{lllllll}
\hline Diet & Moisture (\%) & Crude protein (\%) & Crude fibre (\%) & Ether extract (\%) & Total ash (\%) & Gross energy $\left(\mathrm{kcal} \mathrm{kg}^{-1}\right)$ \\
\hline T0 & $7.66 \pm 1.03$ & $32.74 \pm 0.05$ & $6.62 \pm 0.05$ & $4.42 \pm 0.06$ & $22.34 \pm 0.05$ & $3942 \pm 6.33$ \\
T1 & $8.26 \pm 0.07$ & $32.54 \pm 0.07$ & $4.15 \pm 0.04$ & $8.61 \pm 0.08$ & $22.53 \pm 0.17$ & $3772 \pm 3.46$ \\
T2 & $9.29 \pm 0.08$ & $32.74 \pm 0.04$ & $2.84 \pm 0.05$ & $7.87 \pm 0.06$ & $26.55 \pm 0.06$ & $3538 \pm 5.78$ \\
T3 & $7.26 \pm 0.16$ & $32.61 \pm 0.04$ & $2.34 \pm 0.06$ & $7.57 \pm 0.07$ & $30.84 \pm 0.06$ & $3444 \pm 1.20$ \\
T4 & $11 \pm 0.57$ & $27.66 \pm 2.02$ & $7.06 \pm 0.17$ & $3.00 \pm 0.17$ & $28.32 \pm 1.45$ & $2856 \pm 7.86$ \\
\hline
\end{tabular}

Table. 4. Growth performance of GIFT tilapia fed experimental diets incorporated with different levels of biofloc meal

\begin{tabular}{|c|c|c|c|c|c|c|c|c|c|c|c|}
\hline Diets & $\begin{array}{l}\text { Initial body } \\
\text { weight (g) }\end{array}$ & $\begin{array}{l}\text { Final body } \\
\text { weight (g) }\end{array}$ & $\begin{array}{l}\text { Weight } \\
\text { gain (g) }\end{array}$ & $\begin{array}{l}\text { Survival } \\
(\%)\end{array}$ & $\begin{array}{l}\text { Biomass } \\
\text { gain }(\mathrm{g})\end{array}$ & $\begin{array}{l}\text { Total } \\
\text { biomass (g) }\end{array}$ & $\begin{array}{l}\text { Total feed } \\
\text { intake (g) }\end{array}$ & FCR & FER & PER & SGR \\
\hline T0 & $2.03^{\mathrm{a}} \pm 0.02$ & $27.16^{b} \pm 0.50$ & $25.13^{b} \pm 0.52$ & $96.6^{\mathrm{a}} \pm .3 .32$ & $242.57^{\circ} \pm 3.49$ & $262.07^{\circ} \pm 4.29$ & $292.00^{\mathrm{a}} \pm 3.05$ & $1.11^{\mathrm{a}} \pm 0.01$ & $0.90^{\mathrm{d}} \pm 0.01$ & $7.41^{\mathrm{c}} \pm 0.10$ & $4.32^{b} \pm 0.04$ \\
\hline $\mathrm{T} 1$ & $2.01^{\mathrm{a}} \pm 0.01$ & $25.28^{\mathrm{b}} \pm 0.81$ & $23.26^{\mathrm{b}} \pm 0.81$ & $96.6^{\mathrm{a}} \pm 3.32$ & $224.40^{\mathrm{bc}} \pm 2.62$ & $243.93^{\mathrm{bc}} \pm 2.63$ & $290.33^{\mathrm{a}} \pm 3.48$ & $1.19^{\mathrm{b}} \pm 0.00$ & $0.84^{\mathrm{c}} \pm 0.00$ & $6.89^{\mathrm{bc}} \pm 0.08$ & $4.21^{\mathrm{b}} \pm 0.05$ \\
\hline $\mathrm{T} 2$ & $2.01^{\mathrm{a}} \pm 0.03$ & $22.10^{\mathrm{a}} \pm 0.24$ & $20.09^{\mathrm{a}} \pm 0.23$ & $96.6^{\mathrm{a}} \pm 3.32$ & $194.10^{\mathrm{ab}} \pm 4.89$ & $213.53^{\mathrm{ab}} \pm 5.33$ & $266.33^{\mathrm{a}} \pm 5.69$ & $1.25^{\mathrm{c}} \pm 0.01$ & $0.80^{\mathrm{b}} \pm 0.00$ & $5.93^{\mathrm{ab}} \pm 0.15$ & $3.99^{\mathrm{a}} \pm 0.03$ \\
\hline $\mathrm{T} 3$ & $1.97^{\mathrm{a}} \pm 0.02$ & $20.46^{a} \pm 1.34$ & $18.49 \pm^{\mathrm{a}} 1.31$ & $96.6^{\mathrm{a}} \pm 3.32$ & $177.93^{a} \pm 7.26$ & $194.03^{\mathrm{a}} \pm 5.53$ & $254.00^{\mathrm{a}} \pm 8.62$ & $1.31^{\mathrm{d}} \pm 0.01$ & $0.76^{\mathrm{a}} \pm 0.00$ & $5.45^{\mathrm{a}} \pm 0.22$ & $3.89^{\mathrm{a}} \pm 0.08$ \\
\hline $\mathrm{T} 4$ & $1.98^{\mathrm{a}} \pm 0.00$ & $19.88^{\mathrm{a}} \pm 0.99$ & $17.89 \pm^{\mathrm{a}} 0.98$ & $86.6^{\mathrm{a}} \pm 4.81$ & $156.82^{a} \pm 9.35$ & $174.07^{a} \pm 9.73$ & $238.67^{\mathrm{a}} \pm 8.37$ & $1.37^{\mathrm{e}} \pm 0.01$ & $0.73^{\mathrm{a}} \pm 0.01$ & $4.90^{\mathrm{a}} \pm 0.74$ & $3.84^{\mathrm{a}} \pm 0.07$ \\
\hline \multicolumn{12}{|c|}{ One way ANOVA $(\mathrm{p}<0.05)$} \\
\hline Diet & 0.51 & 0.01 & 0.01 & 0.54 & 0.01 & 0.01 & 0.18 & 0.01 & 0.01 & 0.01 & 0.01 \\
\hline
\end{tabular}




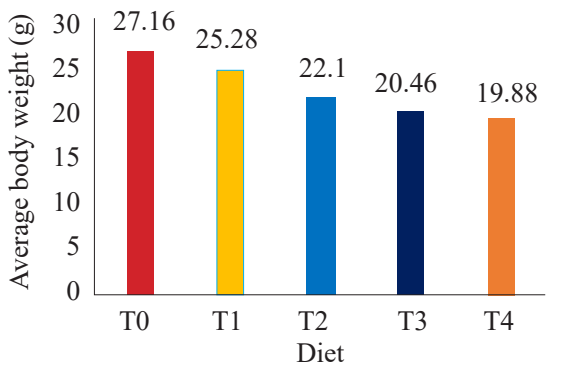

(a)

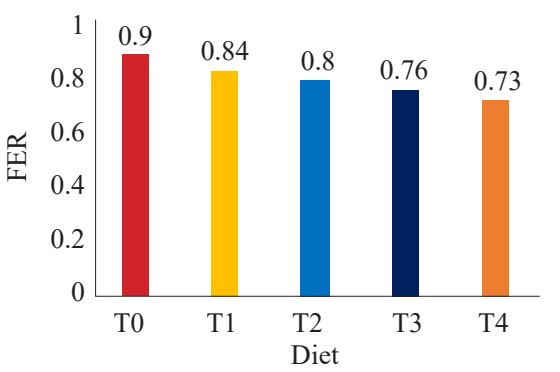

(d)

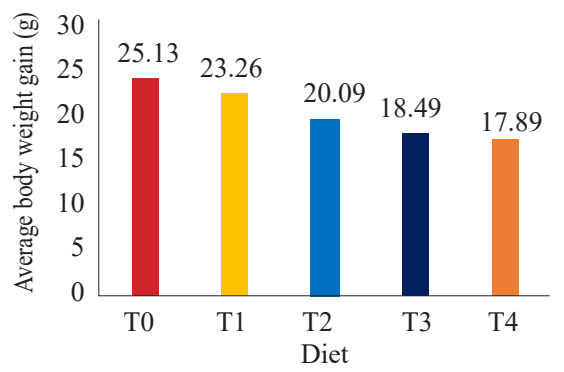

(b)

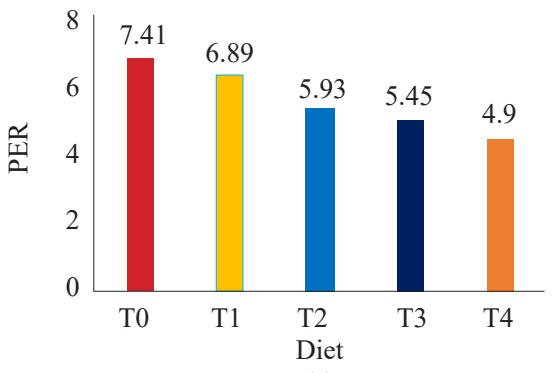

(e)

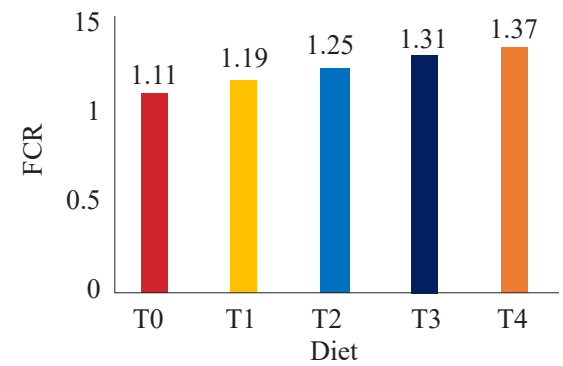

(c)

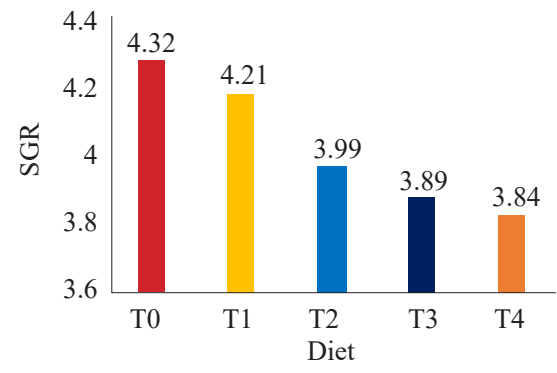

(f)

Fig. 1. Growth parameters of GIFT tilapia fed biofloc meal incorporated experimental diets. (a) Average body weight, (b) Average body weight gain, (c) FCR, (d) FER, (e) PER, (f) SGR

being well within the range reported by Emerenciano et al. (2013), Wasielesky et al. (2006), Faizullah (2015), Hargreaves (2013) and Himaja (2016). Biofloc is usually a poor source of total lipids with concentrations ranging from below 1 to $25 \mathrm{~g} \mathrm{~kg}^{-1}$ (Azim et al., 2008; Avnimelech 2009; Kuhn et al., 2009; Bauer et al., 2012). The ash content of biofloc in the present investigation was $51.28 \%$, which agreed with earlier reports (Soares, 2004; Maica et al., 2012; Mangodu, 2012; Hende et al., 2014; Neto et al., 2015; Suita et al., 2015). High ash content of biofloc may be related to the abundance of acid-insoluble oxides and mixed silicates (Tacon et al., 2002). Accumulated minerals and metals may also contribute to the high ash content. Biofloc may thus be a good source of essential minerals and trace elements (Tacon et al., 2002; Ju et al., 2012) and it may contribute to animal growth (Avnimelech, 2006).

In the present study, the highest mean body weight of GIFT tilapia was recorded in the control, followed by T1, T2, T3 and T4. However, the mean body weight of fish in T1 group fed $20 \%$ biofloc meal did not differ significantly from that of the control. Increase in the dietary biofloc meal level resulted in significant decrease in growth rate and higher FCR when compared with the control. Minimum biofloc meal inclusion (20\%) produced better weight gain and lower FCR than the maximum inclusion level (40\%) which is in agreement with Ajiboye et al. (2012) and Kissling and Askbrandit (1993) who observed reduction in growth rate of fishes at higher levels of microbial supplementation, as microbial products at higher levels tend to reduce feed palatability and digestibility. In the present study, the survival of fish was $95 \%$, with the exception of T4 $(86.6 \pm 0.88 \%)$. FCR was lowest in the control, followed by T1, T2, T3 and T4 that showed higher values. These values fell in the range from 1.10 to 1.50 as reported by Moss et al. (2006), Samocha et al. (2007), Taw et al. (2009), Zhao et al. (2012), Xu et al. (2012), Hussain et al. (2014) and Dantas et al. (2016). PER is used to assess protein utilisation and turnover, where it is related to dietary protein intake and its conversion into fish protein. Ahamed et al. (2004) observed that PER is significantly affected by dietary protein level and ranged from 1.58 to 2.35 for fry, 1.19 to 1.92 for fingerlings and 0.99 to 1.53 for adult Nile tilapia. PER values in the present study ranged from $4.90 \pm 0.74$ to $7.41 \pm 0.10$.

Earlier studies have reported increase in growth rate, general welfare and survival of fishes reared in microbial floc based systems (Tacon et al., 2002); however, studies that have used flocs as ingredients in aquaculture diets are limited. Kuhn et al. (2009) replaced 37\% of fishmeal in shrimp feed, achieving similar performance as diets containing lower replacement levels. In another study, Kuhn et al. (2010) reported no deleterious effects on growth when L.vannamei were fed with diets containing biofloc inclusion from 10 to $30 \%$, regardless of fishmeal substitution of $0-67 \%$. The results of the present study suggest that $20 \%$ biofloc meal in the diet is optimum for the growth of GIFT tilapia. This finding is supported by the results of Himaja (2016) who obtained higher growth of catla by replacing fish meal in the diet with $20 \%$ 
biofloc meal. Dantas et al. (2016) suggested that fish meal replacement by biofloc meal at $20 \%$ improves the growth of L. vannamei, whereas Bauer et al. (2012) stated that fish meal in L. vannamei post-larve diet could be replaced by biofloc meal up to $30 \%$.

The positive effect of the experimental diets on the growth of GIFT tilapia clearly demonstrates that biofloc meal is a viable alternative ingredient and can be used in the diet up to $20 \%$ level. Biofloc meal thus represents an important, alternative ingredient for the development of cost effective feed for fishes, in particular by reducing, dependence on fishmeal as well as environmental impact.

\section{References}

Ahmad, M. H., Abdel-Tawwab, M. and Khattab, Y. A. 2004. Effect of dietary protein levels on growth performance and protein utilisation in Nile tilapia (Oreochromis niloticus L.) with different initial body weights. In: Proceedings of the $6^{\text {th }}$ international symposium on tilapia in aquaculture, Manila, Philippines, p. 249-263.

Ahsan, M. E., Wahab, M. A., Siddik, M. A. B., Alam, M. A., Sharker, M. R. and Nahar, A. 2013. Impacts of inclusion of column feeder rohu (Labeo rohita) at different stocking densities on growth and production in freshwater prawnfinfish polyculture system. Int. J. Biol. Res., 1(2): 48-54.

Ajiboye, O. O., Yakubu, A. F. and Adams, T. E. 2012. A perspective on the ingestion and nutritional effects of feed additives in farmed fish species. World J. Fish Mar. Sci., 4(1): 87-101.

AOAC 1995. Official methods of analysis, $13^{\text {th }}$ edn. Association of Official Analytical Chemists, Washington D. C., USA.

APHA 2005. Standard methods for the examination of the water and wastewater, $22^{\text {nd }}$ edn. American Public Health Association, Washington, D. C., USA

Avnimelech, Y. 2006. Bio-filters: the need for a new comprehensive approach. Aquacult. En., 34(3): 172-178.

Avnimelech, Y. 2009. Biofloc technology. A practical guide book. The World Aquaculture Society, Baton Rouge, USA, $182 \mathrm{pp}$.

Azim, M. E. and Little, D. C. 2008. The biofloc technology (BFT) in indoor tanks: water quality, biofloc composition and growth and welfare of Nile tilapia (Oreochromis niloticus). Aquaculture, 283(1): 29-35.

Ballester, E. L. C., Abreu, P. C., Cavalli, R. O., Emerenciano, M., Abreu, L. and Wasielesky, W. 2010. Effect of practical diets with different protein levels on the performance of Farfantepenaeus paulensis juveniles nursed in a zero exchange suspended microbial flocs intensive system. Aquac. Nutr., 16: 163-172.

Bauer, W., Prentice-Hernandez, C., Tesser, M. B., Wasielesky, W. and Poersch, L. H. 2012. Substitution of fishmeal with microbial floc meal and soy protein concentrate in diets for the pacific white shrimp Litopenaeus vannamei. Aquaculture, 342: 112-116.

Crab, R., Chielens, B., Wille, M., Bossier, P. and Verstraete, W. 2010. The effect of different carbon sources on the nutritional value of bioflocs, a feed for Macrobrachium rosenbergii post-larvae. Aquac. Res., 41(4): 559-567.

Dantas, E. M., Valle, B. C. S., Brito, C. M. S., Calazans, N. K. F., Peixoto, S. R. M. and Soares, R. B. 2016. Partial replacement of fishmeal with biofloc meal in the diet of post-larvae of the Pacific white shrimp Litopenaeus vannamei. Aquac. Nutr., 22(2): 335-342.

Duncan, D. B. 1995. Multiple range and multiple (F) tests. Biometrics, 11: 1-42.

Eknath, A. E. and Hulata, G. 2009. Use and exchange of genetic resources of Nile tilapia (Oreochromis niloticus). Rev. Aquac., 1(3-4): 197-213.

Emerenciano, M., Cuzon, G.,Arevalo, M., Miquelajauregui, M.M. and Gaxiola, G. 2013. Effect of short-term fresh food supplementation on reproductive performance, biochemical composition and fatty acid profile of Litopenaeus vannamei (Boone) reared under biofloc conditions. Aquac. Int., 21(5): 987-1007.

Faizullah, M., Rajagopalsamy, C. B. T., Ahilan, B. and Francis, T. 2015. Impact of biofloc technology on the growth of goldfish young ones. Indian J. Sci. Technol., 8(13): 3-6.

FAO 2010. The state of world fisheries and aquaculture 2010. Food and Agricultural Organisation, Rome, p. 18-25.

Fitzsimmons, K. 2005. Tilapia culture. In: Kelly, A. and Silverstein, J. (Eds.), Aquaculture in the $21^{\text {st }}$ century, The American Fisheries Society, Maryland, USA, 643 pp.

Hargreaves, J. A., 2013. Biofloc production systems for aquaculture. Southern Regional Aquaculture Center. SRAC publication, p. 3-10.

Hende, S. F. D., Claessens, L., Muylder, E. D., Boon, N. and Vervaeren, H. 2014. Microbial bacterial flocs originating from aquaculture wastewater treatment as diet ingredient for Litopenaeus vannamei (Boone). Aquac. Res., 47: 1075-1089.

Himaja, P. H. S. 2016. Performance of biofloc meal in the diet of catla, Catla catla (Hamilton, 1822). M. F. Sc. dissertation, Fisheries College and Research Institute, Thoothukudi, Tamil Nadu Fisheries University, India.

Hussain, A. S., Mohammad, D. A., Ali, E. M. and Sallam, W. S. 2014. Nutrient optimisation for the production of microbial flocs in suspended growth bioreactors. J. Arabian Aquac. Soc., 9(1): 113-126.

Ju, Z. Y., Deng, D. F. and Dominy, W. 2012. A defatted microalgae (Haematococcus pluvialis) meal as a protein ingredient to partially replace fishmeal in diets of Pacific white shrimp (Litopenaeus vannamei, Boone, 1931). Aquaculture, 354: 50-55. 
Kiessling, A. and Askbrandt, S. 1993. Nutritive value of two bacterial strains of single-cell protein for rainbow trout (Oncorhynchus mykiss). Aquaculture, 109(2): 119-130.

Kuhn, D. D., Boardman, G. D., Lawrence, A. L., Marsh, L. and Flick, G. J. 2009. Microbial floc meal as a replacement ingredient for fish meal and soybean protein in shrimp feed. Aquaculture, 296(1): 51-57.

Kuhn, D. D., Lawrence, A. L., Boardman, G. D., Patnaik, S., Marsh, L. and Flick, G. J. 2010. Evaluation of two types of bioflocs derived from biological treatment of fish effluent as feed ingredients for Pacific white shrimp, Litopenaeus vannamei. Aquaculture, 303(1): 28-33.

Luo, G., Gao, Q., Wang, C., Liu, W., Sun, D., Li, L. and Tan, H. 2014. Growth, digestive activity, welfare and partial cost-effectiveness of genetically improved farmed tilapia (Oreochromis niloticus) cultured in a recirculating aquaculture system and an indoor biofloc system. Aquaculture, 422: 1-7.

Magondu, E. W. 2012. Aerobic, anaerobic and anoxic bioflocs from tilapia: Proximate composition, nutritional properties and attractiveness as fish feed. Master's thesis, Wageningen University, The Netherlands.

Maica, P. F., de Borba, M. R. and Wasielesky Jr., W. 2012. Effect of low salinity on microbial floc composition and performance of Litopenaeus vannamei (Boone) juveniles reared in a zero-water-exchange super-intensive system. Aquac. Res., 43(3): 361-370.

Megahed, M. E. and Mohamed, K. 2014. Sustainable growth of shrimp aquaculture through biofloc production as alternative to fishmeal in shrimp feeds. J. Agric. Sci., 6(6): 176-184.

Moss, R. E., Seed, R. B., Kayen, R. E., Stewart, J. P., Der Kiureghian, A. and Cetin, K. O. 2006. CPT-based probabilistic and deterministic assessment of in situ seismic soil liquefaction potential. J. Geotech. Geoenviron. En., 132(8): 1032-1051.

Neto, H. S., Santaella, S. T. and Nunes, A. J. P. 2015. Bioavailability of crude protein and lipid from biofloc meals produced in an activated sludge system for white shrimp, Litopenaeus vannamei. Revista Brasileira de Zootecnia, 44(8): 269-275.
Samocha, T. M., Patnaik, S., Speed, M., Ali, A. M., Burger, J. M., Almeida, R. V., Ayub, Z., Harisanto, M., Horowitz, A. and Brock, D. L. 2007. Use of molasses as carbon source in limited discharge nursery and grow-out systems for Litopenaeus vannamei. Aquac. En., 36(2): 184-191.

Scorvo Filho, J. D., Frasca-Scorvo, C. M. D., Alves, J. M. C. G. N. A. and Souza, F. R. A. D. 2010. A tilapicultura e seus insumos, relações econômicas. Revista Brasileira de Zootecnia, 39: 112-118.

Soares, R., Jackson, C., Coman, F. and Preston, N. 2004. Nutritional composition of flocculated material in experimental zero-exchange system for Penaeus monodon. Proc. Australian Aquac., 89(2): 144-152.

Suita, S. M., Cardozo, A. P., Romano, L. A., Abreu, P. C. and Wasielesky Jr., W. 2015. Development of the hepatopancreas and quality analysis of post-larvae of Pacific white shrimp Litopenaeus vannamei produced in a BFT system. Aquac. Int., 23(2): 449-463.

Tacon, A. G. J., Cody, J. J., Conquest, L. D., Divakaran, S., Forster, I. P. and Decamp, O. E. 2002. Effect of culture system on the nutrition and growth performance of Pacific white shrimp Litopenaeus vannamei (Boone) fed different diets. Aquac. Nutr., 8(2): 121-137.

Taw, N. 2010. Biofloc technology expanding at white shrimp farms. Global Aquac. Adv., p. 146-154.

Wasielesky, W., Atwood, H., Stokes, A. and Browdy, C. L. 2006. Effect of natural production in a zero exchange suspended microbial floc based super-intensive culture system for white shrimp Litopenaeus vannamei. Aquaculture, 258(1): 396-403.

Xu, W. J., Pan, L. Q., Zhao, D. H. and Huang, J. 2012. Preliminary investigation into the contribution of bioflocs on protein nutrition of Litopenaeus vannamei fed with different dietary protein levels in zero-water exchange culture tanks. Aquaculture, 350: 147-153.

Zhao, P., Huang, J., Wang, X. H., Song, X. L., Yang, C. H., Zhang, X. G. and Wang, G. C. 2012. The application of bioflocs technology in high-intensive, zero exchange farming systems of Marsupenaeus japonicus. Aquaculture, 354: 97-10. 